Vol. 1, No. 1, 2020

\title{
ISLAMIC EDUCATION IN DEVELOPING STUDENTS' CHARACTERS AT AS-SHOFA ISLAMIC HIGH SCHOOL, PEKANBARU RIAU
}

\author{
${ }^{1 *}$ Eniwati Khaidir, ${ }^{2}$ Fitriah M. Suud \\ ${ }^{1}$ Universitas Islam Negeri Sultan Syarif Kasim Riau, ${ }^{2}$ Universitas Muhammadiyah Yogyakarta \\ 1*eniwati_khd@yahoo.com, ${ }^{2}$ fitriahmsuud@gmail.com
}

\section{ARTICLE INFO}

\section{Article history}

Received 11/1/2020

Revised 9/2/2020

Accepted 10/4/2020

\section{Keywords}

Islamic Education

Character Building

Education Process

Integrated School

Qur'an and Hadith

\begin{abstract}
Education must have a good and robust foundation, because with this foundation, the direction of the implementation of education is not merely a momentary shock or turmoil. The foundation of knowledge is an essential in the process of advancing education. Thus, the basis of education is a fundamental problem because the primary school will determine the style and content of learning. In the meantime, its relation to Islamic teaching, the basis or foundation of Islamic education, is the foundation that forms the basis or principle to stand tall. Therefore, the basis of Islamic culture must be considered comprehensively in revealing through the next educational steps. AlQur'an and Hadith are sources of Islamic law and complete knowledge, covering the whole of human life, both the world and the hereafter. Both become an apparent clue for humans and the pace of their lives at all times. Al-Qur'an and Hadith, as a basis for Islamic education as well as a source of shari'a teachings, not only work as a book but also exploration for daily life. Islam is a religion that carries a mission so that people conduct education and teaching. This is an open access article under the CC-BY-SA license.
\end{abstract}

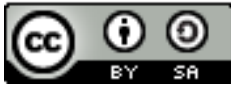

\section{INTRODUCTION}

Islamic Education is an effort made systematically in guiding students who are Muslim, so that Islamic teachings are genuinely known, owned, and practiced by students both reflected in their attitudes and ways of thinking. Through religious education, the process of developing aspects of the personality of the child occurs, namely cognitive aspects, affective aspects, and psychomotor aspects. Spiritual teachings should become an integral part of the child's character in the sense that all children's activities will reflect the Islamic attitude.

Education plays an essential role in shaping the quality of believing and pious people. People with conditions can act wisely both in their capacity as leaders for 
themselves, their families, and communities. In the decree of the MPR, national development in the field of education is to educate the life of the nation and improve the quality of Indonesian people in realizing an advanced, prosperous society, and to enable its citizens to develop themselves both about physical and spiritual aspects (Sabri, 1995).

Islamic Education is physical and spiritual guidance based on Islamic religious laws leading to the formation of the leading personality according to Islamic measures (Marimba, 1962). The teachings of al-Qur'an are full of values of knowledge that require followers to know various natural phenomena to consider. Al-Hadith is also a great source of knowledge for Islam, which is, at the same time, an interpreter, and an integral part of the Qur'an. According to Husein Nasr, the Prophet's Hadith discusses various things, ranging from metaphysics to order at the dinner table (Munawwaroh \& Tanenji, 2003).

Islamic religion requires its worshippers to live their teachings that originate from the Qur'an and al-Hadith, for example, religious education, which does not only aim at gaining knowledge and skills but also personal inculcation and a positive attitude in teachers and students. This fact is in line with the opinion of Zakiyah Daradjat by her mentions that Islamic religious education is not just teaching religious knowledge and training students' skills in performing worship. It is more than that. It first aims to shape the personality of students, following spiritual teachings, fostering attitudes, mental and morals, followed by clever memorization of the propositions and religious laws, which are not absorbed and lived in life "(Daradjat, 2005). Thus, Islamic education is the basis for living a life according to the Qur'an and Hadith. Religion works like the eye, while science is a microscope or telescope that can clarify the power of eye observation or belief is a guide and a way of life towards safety.

\section{METHODS}

This research is qualitative research with a case study approach. The qualitative research to collect data taken by observation, interview and documentation study. The informants in this study were teachers in As-Shofa Islamic High School, Pekanbaru Riau. In addition to the research teacher also gets research information from students and parents of the student. Some of the important points of this research also involve non-teacher employees such as cleaning services and others who do not directly associate with student character education, but they provide development in shaping student character. To get accurate results from the results of the study, triangulation is carried out to ensure that there are obtained in accordance with reality. 


\section{RESULT AND DISCUSSION}

\section{A. Character Building in Education}

The Nature of Character in Education

Nowadays, the government has a unique interest in character education. This condition is understandable where Indonesia has undergone various changes to reach the peak of world civilization. In the process of change, character education is a necessity, because there will be a peak of world civilization if the nation has a strong character. In the world of education, especially in Indonesia, character education is not a foreign term. Language in an extensive dictionary in the Indonesian language means the mental characteristics that distinguish one person from another (Ministry of National Education, 2008).

Meanwhile, in English, the word 'character' stays the same (John M. Echols \& Hassan Shadily, 1992). In Greek, word character comes from the word charassein, which means goods or tools for scratching. It can also mean a stamp. This word means that a character is a real inherent and permanent nature shown by individuals. Character is a way of thinking and behaving demonstrated by individuals. The behaviour is a characteristic of an individual to live and work together with the family, community, and nation. Thus, individuals of good character are the ones who can make decisions and take responsibility for the consequences of the choices they make (Suyanto et al., 2018). Further, a character is a set of traits as signs of goodness, wisdom, and moral maturity of a person.

The character is a quality of mental and moral strength shown by everyone who can distinguish between one another. A character is inherent and possessed by someone who can be a motivator or mobilizer in doing an action or act. Therefore, character education is essential for the nation because it concerns the issue of the transfer of generations in process and must run continuously. The character education process will involve various aspects of student development, such as cognitive, affective, and psychomotor aspects as a whole (Mujib, 2017). Character education requires examples. It is because examples give a considerable contribution in shaping character and habit through parenting at home. Also, teachers at schools and communities in environments have the same responsibilities. The students must have discipline and honesty (Suud, Madjid, \& Sutrisno, 2019) to be friendly and affectionate.

Akhlaq or Islamic morals or character is the main target in education seen from many prophetic traditions that explain the virtues of moral education. The Prophet's hadith, which states that: "teach your children good and educate them" (Rusn, 1998). This word means educating children towards goodness is a necessity. Children can become human beings who have moral values so that later they should become perfect humans (insan kamil) (Setiawan, 2016) following their function as khalîfah fî al-ard (Tambak \& Sukenti, 2020). Someone can have character when they have been able to absorb and, at the same time, implement moral and moral values based on the nature and purpose of Then, 
those abilities become the characteristics, or style of a person from the formations or internalization received from the informal environment (family) or obtained through the formal environment (school) and the informal environment (public).

Mu'in and Doni Koesoema also states the same argument. They mention that the term personality is closely related to the term character, where personality is the totality of values that direct humans in living their lives. The character has an association with the value system of someone. Someone is mature when he can show consistency in his character. The character itself exists due to a person's experience in his life. Thus, the order and life situation ultimately determine the formation of a person's character. For example, when someone wants to judge other people, then surely, he will see his personality. This example means that the personality of a good person will have a reflection on his behaviour as pleasant and exciting. Still, on the contrary, a bad character will look annoying and will dislike and feel uncomfortable being friends with them.

The character itself is the attitudes and behaviour that appear in everyday life. Character is interpreted as a unique way of thinking, saying, and behaving of every individual to live and work together with the family, community, and nation. Good character individuals are individuals who can make decisions and are ready to take responsibility for the consequences of their choices. A character can also education, such as honesty, example, courtesy, respect, mutual respect, love, humility, and help. Therefore, the term character is closely related to personality (McCrae \& Costa, P. T., 2003). When someone becomes a person, he can show behaviour following the moral rules of religion and social norms that apply in society (Mu'in, 2011).

In contrast, Koesoema states that "character equals personality" (2010). This statement means that personality is an image of the individual to behave, speak, and think. be values of human behaviour related to oneself, God Almighty (habl min Allah) and other fellow humans (habl min al-nas) as well as behaviour related to the environment, and nationality manifested in thoughts, attitudes, feelings, words, and actions based on religious, social, legal, etiquette, cultural, cultural, and aesthetic norms (Samani \& Hariyanto, 2013).

As understood, a character is a spiritual trait imprinted in human beings, which can be the identity of one's behaviour. The identity reflected in the activities appears in the form of behaviour that can be a differentiator between good and bad humans. In each Educational Institution, character education ideally leads to the strengthening and development of children's behaviour, based on a particular value that is following the morality of religion, nation, and country. Therefore, character education is education integrated with learning that occurs in all subjects without exception since children/students are human organisms 
that have the potential to be developed. The development of such behaviour is according to the values referred to by schools (Koesoema, 2010).

There are some abilities can be developed from students, such as: intellectual, spiritual intelligence, and social intelligence. The students become noble individuals who serve the mighty God. They can live as a harmonious society with a residential environment and the ability to make the world a vehicle for safe, prosperous, and outer and inner prosperity. In the effort of character building, the role of As-Shofa Islamic High School is significant, because it must involve various components of education, namely teachers, principals, and all stakeholders, through all school activities to shape the character, character, or personality of students. The formation of character is also inseparable from the role of a hidden curriculum that is carried out by As-Shofa Islamic High School. Therefore, character building with religious values and national personality is a necessity.

Character education has four essential characteristics (Koesoema, 2010), first, interior order in which every action is measured based on a set of values. This statement means that values become benchmarks and normative guidelines in every behaviour and action. Second, a coherence gives courage and makes someone stick to the principle and various situations. This character will undoubtedly be able to build mutual trust with one another. Third, autonomy means that someone internalizes values from the outside so that they become personal values. Of course, this character will become a trait attached to a person so that he can commit and make his own decisions. Fourth, constancy, and loyalty. Persistence is the strength and endurance of someone to maintain what is considered good, and loyalty is the basis for respect for commitments chosen honestly, good and right, so that determination and loyalty is a disposition relied upon in responding to various situations.

\section{B. Character Building from an Islamic Perspective}

The basis for the formation of character is a good or bad value. Angels symbolize good values, and satan express bad values. Human character is the result of the attraction between good value in the form of positive energy and bad value in the form of negative energy. Positive energy is in the form of religion. Ethical values come from belief in God, while the negative energy is in the form of a-moral values that come from thaghut (Satan). These moral-ethical values function as a means of purification, purification, and generation of real human values (conscience). Positive energy is in the form of first, spiritual power. Spiritual strength in the form of faith, Islam, ihsan, and taqwa serves to guide and give strength to humans to reach greatness and glory (ahsani taqwim). Second, the power of positive human potential is in the form of aqlus salim (healthy mind), qalbun salîm (healthy heart), qalbun munîb (returning heart, clean, clean from sin) and nafsul mutmainnah (calm soul). All of which constitute human capital or human resources who have extraordinary powers. Third, ethical attitudes and behaviour. These ethical attitudes and behaviours are the 
implementation of spiritual strength and the strength of human personality, which then gives birth to normative concepts about ethical, cultural values. Ethical attitudes and behaviour include istiqamah (integrity), sincerity, jihad, and sholeh charity (Tobroni, 2008).

The positive energy from the perspective of individuals will give birth to people of character, namely people who are pious, have integrity (nafs al-mutmainnah), and do good deeds. The actualization of this quality person in life and work will give birth to a noble character because it has a personality (integrity, commitment, and dedication), capacity (skill), and good competency (professional) as well. The opposite of positive energy above is negative energy. The materialistic power and the values of the thaghut (destructive values) symbolize negative energy. If ethical values function as a means of purification, purification, and generation of real human values (conscience), material values (thaghut) function oppositely, namely decay, and embezzlement of human values.

Similar to positive energy, negative energy consists of, first, the power of thaghut. The power of thaghut is in the form of kufr (disbelief), munafiq (hypocrisy), fasiq (wickedness), and syirk, all of which are forces that keep people away from ethical creatures and their essential humanity (ahsani taqwîm) into all material (asfala sâfilîn). Second is negative human strength, namely the ignorant mind (heretical thoughts), qalbun maridl (sick heart, not feeling), qalbun mayyit (dead heart, no conscience), and lust lawwamah (despicable soul). All of them will make servants to gods other than Allah in the form of wealth, sex, and power (thaghut). Third is unethical attitudes and behaviours. This unethical attitude and behaviour is an implementation of the power of the thaghut and negative humanitarian forces, which then gives birth to normative concepts about unethical cultural values (foul culture). Unethical attitudes and behaviour include takâbur (arrogant), hubb al-dunya (materialistic), dzalim (persecution), and sayyiat charity (destructive).

Negative energy from the perspective of individuals will give birth to people of bad character, namely people whose peak of badness includes syirk, nafs law, and al-Sayyiat (destructive). The actualization of people with the mentality of thaghut in life and work will give birth to despicable behaviour, namely people who have bad personalities (hypocritical, traitors, and cowards) and people who are unable to utilize their competencies as recognized by Hadrawi, Vice Principal of As-Shofa Islamic High School Pekanbaru carried positive energy as expressed in the following interview: "We admit, in As-Shofa Islamic High School, there are also students who give negative energy. For students with positive energy, it is easy for us to direct and guide them in the right direction. However, for students with negative energy, it is challenging to be fostered and tends to commit violations. What we are concerned about is that students with negative energy tend to influence other students to commit abuses. Our efforts, yes, as much as possible, we prevent this influence. " 
The highlight of a Muslim's character is taqwâ, and his indicator of devotion lies there. Character is built based on an understanding of the nature and structure of the human personality integrally. People with taqwa is a picture of an ideal human being, a human with spiritual intelligence (spiritual quotient). It is this spiritual intelligence emphasized in education done by inculcating religious, ethical values through the example of family, school, and community, strengthening the practice of worship, reading, and living the Holy Qur'an, creating a conducive physical and social environment. When the child's spirituality has a good organization, it will be easier to arrange other aspects of personality (Sudirman, S. A, 2019). That is, if the child's spiritual intelligence successfully increases, it will automatically increase other intelligence, such as emotional intelligence (emotional quotient), intelligence solving problems (adversity quotient), and intellectual intelligence (intellectual quotient). It is the key to why religious-based educational activities are more successful in shaping children's personalities (Azimabadi, 2000).

Cohesion, harmony, and the illumination of Godspot (spirit) towards the heart, mind, lust, and body clearly will maximize the intelligence and function of each. In the context of educational goals, this will be able to form students who have the strength of faith (quwwatul aqîdah), depth of knowledge (quwwatul ilmi), sincerity in service (quwwatul khidma) and personal nobility (akhlâqul karîmah). The formation of character should depart from the basic human concept: nature. Every child is born according to his nature, which has reason, lust, body, heart, and spirit. This concept has the development of multiple intelligence. In Islam, several terms are appropriate as a learning approach (Mujib, 2017). These concepts include tilâwah, ta'lîm', tarbiyah, ta'dî̀, tazkîyah, and tadrîb (Tafsir, 1996). Tilâwah concerns the ability to read. Ta'lim has a relation to the development of intellectual intelligence (intellectual quotient). Tarbiyah involves caring and compassion instinctively in which there is sharpening, caring, and caring. $T a^{\prime}$ dîb is related to the development of emotional intelligence (emotional quotient). Tazkiyah is associated with the development of spiritual intelligence (spiritual quotient), and tadrîb is similar to physical intelligence or skills (physical quotient or adversity quotient) (Martins et al., 2019) following the educational goals developed for character building.

The recitation method aims to develop children's fluency in speaking and sensitivity in seeing phenomena and reading skills. The ta'lim method develops the potential of nature in the form of reason. It is a method of science and technology education that emphasizes the development of cognitive aspects through teaching. In education, the goal is the formation of students who have far-sighted, creative, and innovative thinking. The output is a child to have a scientific attitude, ulûl albâb, and mujtahid. Ûlul albâb is a person who can utilize the potential of thought (intellectual intelligence / IQ) and the potential of dhikr to understand the phenomenon of God's creation and can use it for the benefit of humanity (Hasibuan, 2019). 
In contrast, a mujtahid is a person capable of solving problems with his intellectual abilities. The result is that ijtihad (its actions) can be in the form of science or technology. The outcome from the education of reason (IQ) is to form of a pious child (waladun shâlih).

C. History of Pekanbaru As-Shofa Foundation Riau

As-Shofa Foundation is an educational institution. The first educational institution under the auspices of this foundation is the "As-Shofa Islamic Primary School," starting from Ust. Dr. H. Syafwi Khalil, M.Pd, a member of IKMI preacher who wanted to develop a Quality Islamic Educational Institution in Pekanbaru. Nowadays, the As-Shofa Foundation has its land and building located on Jl. T. Tambusai / Jl. As-Shofa Pekanbaru. As a long-term realization of the foundation, this area has established the As-Shofa Islamic Middle School (2000), the As-Shofa Islamic Kindergarten School (2005), and As-Shofa Islamic High School (2007).

Ustadz Syafwi had the dream while leading the Islamic Boarding School AlHikmah Foundation, Pekanbaru. When the madrasa that he led showed a development, at that moment, challenges were blocking his steps. The main obstacle he faced at that time was the madrasa students who were elementary school students. Elementary school students who were VI grades must leave the madrasa often because they had to take additional classes in the late afternoon. Madrasa students often left their lessons, causing the goals to difficult to reach. Then, his wife, Yulia Eriswati, had an idea to establish an elementary school that had classes from morning to late afternoon (Full Day School). They gave the school "As-Shofa Islamic Elementary School," as a name taken from the name of the founder.

As-Shofa Islamic Elementary School in the first year of its establishment in 19911992 only had ten students. The first principal was Ibu Salimah Harahap, BA, and assisted by four teaching staff. Since the As-Shofa Foundation did not have room facilities for study yet, the foundation's management strived to borrow an upper room of the Surya Mosque, located on Cempaka District Sukajadi, Pekanbaru. With the permission of the chairman of the mosque, Mukni, AsShofa Islamic Primary School could occupy the room for one year.

In the next academic year, the number of students increased so that the board of the As-Shofa Foundation tried to find an adequate place located near the first location with a lease/loan status for four years, located on Melati, Sukajadi Subdistrict, owned by one of the communities (The late, Barmawi). As-Shofa Foundation was able to buy its land on 1997 and build more representative buildings and other learning facilities located on Tuanku Tambusai.

Seeing the development of students and the public's trust, triggering and spurring the foundation, always try and implement a system that can shape the personality and skills of superior students, referring to the four pillars of education. They are learning to know, learning to do, learning to be, and 
learning to live together. Pekanbaru Riau As-Shofa Foundation hopes for good cooperation between the school and parents of students so that the As-Shofa Pekanbaru Islamic High School can be the best in Pekanbaru.

\section{Character Values Formed Through The Action Programme}

The character-building process conducted at As-Shofa Islamic High School through the AKSI (Islamic Spiritual Activity Application) program is a superior program because all the programs contain Islamic values to shape the positive character of students. These values include five aspects of the program. They are the first program of faith (iman), morals (akhlaq), and manners, the second program of Fardhu, the third program of Sunnah, the fourth program of interaction with the Qur'ân and the fifth program of Science, $D a{ }^{\prime}$ wah and Islamic Insight.

Through the above programs, the founders expect the students to build values related to hablu minan Allah (human interaction with God) and hablu minan annas (human interaction with other humans). Further, these programs are activities that direct students into positive character values. Therefore, the formation of character and character is a pillar of excellence in As-Shofa Islamic High School, Pekanbaru. Through various forms of activities (AKSI Program), aspects of character formation that have not been optimal can have optimum development. Values come from a process of student interaction with other students as well. Interactions established are expected to build positive behaviour.

Developing humanist values from educational institutions, Krathwohl divides the process of forming and developing values in the students in four stages (Krattwohl, Bloom \& Masia, 2004).

1. Receiving (listening and receiving) means that the child, through the learning process, can actively listen and accept what the teachers have conveyed.

2. Responding (responding), through the children's abilities, they have begun to react and try to understand and digest various knowledge and information.

3. Valuing (giving value), in this third stage, the child already has positive and negative perceptions of the problems received and experienced. The children, then, have been able to give or determine good and bad values.

4. The organization, through this last stage, children can choose and sort, reject, or accept and regulate their attitudes and behaviour.

\section{E. Character Building Model of Islamic Education In Islamic As-Sshofa High School Pekanbaru, Riau}

The model of character formation in Islamic education at As-Shofa Islamic High School was compiled based on the research findings. The reason for formulating the model is because As-Shofa Islamic High School has succeeded in instilling 
character values realized by students through forms of deeds conducted within the school environment, family environment, and community environment. However, not all character values have proper development. There are still deficiencies in its implementation. For example, in the value of discipline, there are still students who still violate the rules. Even so, the community considers that As-Shofa Islamic High School has excelled in akhlaqul karimah as the advantage compared to other high schools in Pekanbaru.

Before formulating the character-building model, it is necessary to first explain between character education and character formation. Character education is a conscious and earnest effort of a teacher to work on the values of his students. Character education can also be an attempt to educate children to make wise decisions and practice them in their daily lives so that they can make a positive contribution to their environment. So, character education is education to shape one's personality through character education, the results seen in one's actual actions, namely: ethical behaviour, honest, responsible, respecting the rights of others, and hard work.

Character education is a serious effort where positive personality traits have developed, encouraged, and empowered through example, study (history and biography of pre-wise and great thinkers), as well as the practice of emulation (maximum effort to realize the wisdom of nothing learned). Furthermore, character education contains three main elements, namely knowing goodness, loving-kindness, and doing a good. So that character education is ultimately also related to peace education (Chaer, 2017a). Meanwhile, character building is an effort that involves all parties, both parents, schools, the school environment, and the wider community. Therefore, character-building will not succeed if all educational environments do not have continuity, cooperation, and harmony. Character building is an essential part of the education process in the family. In general, every parent expects their children to be competent in their fields and of good character.

The most critical element in the formation of character is the mind because it is the pioneer of everything. Inside the mind, all programs come from life experiences. This program then creates a belief system that can build thinking patterns to influence behaviour. There are several things to consider in shaping the character of students, namely habituation of polite behaviour, awareness of cleanliness, tidiness, order, honesty (Suud \& Subandi, 2018), and discipline. Thus, the formation of character is an effort done by parents to influence the child's character. Parents help shape the character of children by giving examples, ways of speaking or conveying tolerance, and other related matters.

The formation of student character is essential but challenging because it needs a long process and lasts a lifetime. In the implementation process, reward and punishment also need consideration (Setiawan, 2018). Moreover, the character is not what a child has since he was born, but through a variety of experiences. 
The formation of student characters can be through the development of one's personality. However, because humans live in particular social and cultural environments, the development of a character can only be done in the relevant social and cultural environment (Suud, 2018). Character development exists in an educational process that does not release students from the social environment, society, and national culture. The social and cultural environment of the nation is Pancasila. Hence, cultural and character education is to develop the values of Pancasila through the heart, brain, and physical. Education in the direction of forming the character of students is the responsibility of all teachers. Therefore, the guidance must also be by the teacher. Thus, it is not quite right to say that educating students to have good character is only given to the teacher of certain subjects.

Formation of character in As-Shofa Islamic High School is more emphasized through the implementation of the AKSI Program. The uniqueness of the AKSI Program can be a model for other schools where public schools that are not religious schools or Islamic boarding schools can instill the character of the morality of Karimah and even become the hallmarks of As-Shofa Islamic High School. Al-Ghazali argues that two human images are related to moral issues, namely, first, the outward human image, which is called the khalq, and secondly, the inner image, which is called the khuluq. Khalq is interpreted here as a physical image of humans, while khuluq is a psychological image of humans. According to Al-Ghazali, khuluq is "a condition (hay'ah) in the soul (nafs) that is sacred (rasikhah), where the condition gives birth to activities that do not require thought and consideration first." Ibn Maskawaih also expressed the same, almost empty understanding that khuluq is a condition (hâl) of the soul (nafs) that causes an activity without thinking or considered beforehand.

The factors of character formation include external factors and internal factors. External factors are in the form of culture and values. The culture that grows and continues to develop during society is one of the factors that can shape and influence character. Likewise, the values caused by the rapid and rapid development of technological science today also contribute to building human character. Thus, a person's character is inseparable from external influences such as culture and values that exist around human life. Herein lies the duties and responsibilities of parents at home and teachers at school to be responsive to the development of culture and values that occur in society.

Internal factors are in the form of actualization of potential. The individual character itself will, in essence, come from a person's attitude and behaviour in his daily life. Therefore, each person has a different character from one another. So that with the uniqueness of its character, then someone will be able to express his strengths. The process of actualizing one's potential must be able to choose and sort out what needs actualization and control. The two factors of character formation are different. After all, these two factors are unavoidable. For this reason, Islamic education conducted both at home, school, and during society 
must include the process of transforming cultural values and the actualization of the potential of students based on religion and norms that exist in society. Its goal is to build students as human beings. Humans who have perfect and robust character, know and are aware of themselves as God's creatures, and can interact with others and their environment.

To form good character in students, it will be faster if the students have a motive for learning and change for good. Understanding the motives cannot be separated from the term needs or needs, which is a situation in which individuals feel the lack or absence of something they need (Chaer, 2017). Maslow, using the term needs (need) as a particular deficiency in an organism. For humans, the term needs already contain a broader meaning, not only physiological but also psychological. The relationship between motives, motivation, drives, and needs (needs) is close and difficult to separate. Although these four terms have variations in meaning, both of them include conditions that encourage individuals to do something. Those conditions are called motivation (Kesuma, Dharma, Triana, 2012).

\section{CONCLUSION}

Based on the results of research, the concept of character education in Islamic psychology is education to form praiseworthy characters (akhlaq mahmudah), such as patience, gratitude, sincere, qana'ah, humble (tawadhu'), honest (sidq), generous (jud), trustful, forgiving, graceful; and to avoid the formation of despicable character (akhlaq madzmûmah). This despicable character forms such as irritability (ghadhab), kufr, riya', greedy (thama'), arrogant (takabur), lie (kidb), stingy (shukh), betrayal, revenge, and envy. The character-building process conducted at As-Shofa Islamic High School through the Islamic Spiritual Activity. There are important values in the educational character that include aspects of faith (iman), morals (akhlaq), and manners. The character building also carries out through worship Fardhu, Sunnah, interaction with the Qur'ân, and Islamic science Program. 


\section{REFERENCES}

Badar Azimabadi. (2000). Etiquettes of Islamic Life, Adam Publisher, and Distributors. Kuala Lumpur.

Chaer, M. T. (2017a). Islam dan Pendidikan Cinta Damai. Istawa: Jurnal Pendidikan Islam, 2(1), 73. https:/ / doi.org/10.24269/ijpi.v2i1.363

Chaer, M. T. (2017b). Peran madrasah dalam menghadapi era globalisasi dan budaya. Muaddib: Studi Kependidikan Dan Keislaman, 6(2), 182. https:// doi.org/10.24269/muaddib.v6i2.461

David R. Krattwohl, Benjamin S. Bloom, \& Betram B. Masia. (2004). Taxonomi of Educational Objectives Handbook II. Affective Domain. London: Longman Group.

Departemen Pendidikan Nasional. (2008). Kamus Besar Bahasa Indonesia. Jakarta: Pusat Bahasa.

Derajat, Z. (2005). Ilmu Jiwa Agama, Cet Ke-17, Bulan Bintang. Jakarta: Bulan Bintang. Djunaidatul Munawwaroh, \& Tanenji. (2003). Filsafat Pendidikan: perspektif Islam dan Umum. Jakarta: UIN Jakarta Press.

Hasibuan, A. (2019). Menyikapi Ulul Albab dalam Alquran. Studi Multidisipliner: Jurnal Kajian Keislaman, 6(2), 1-14. https:/ / doi.org/10.24952/Multidisipliner.V6I2.2082

John M. Echols \& Hassan Shadily. (1992). Kamus Indonesia Inggris. Jakarta: PT. Gramedia.

Kesuma, Dharma, Cepi Triana. (2012). Pendidikan Karakter Kajian Teori Dan Praktik di sekolah. Yogyakarta: Remaja Rosda Karya.

Koesoema, D. (2010). Pendidikan Karakter : Strategi Mendidik Anak di Zaman Global. Jakarta: Gramedia.

Marimba, A. D. (1962). Pengantar Filsafat Pendidikan Islam, Cet. Ke-4. Bandung: AlMa'arif.

Martins, D. S., Hasse-Sousa, M., Petry-Perin, C., Arrial-Cordeiro, R. T., Rabelo-daPonte, F. D., Lima, F. M., Czepielewski, L. S. (2019). Perceived childhood adversities: Impact of childhood trauma to estimated intellectual functioning of individuals with bipolar disorder. Psychiatry Research, 274, 345-351. https:// doi.org/10.1016/j.psychres.2019.02.046

McCrae, R. R., \& Costa, P. T., J. (2003). Personality in Adulthood: Five-Factor Theory Perspective. New York: The Guildford Press.

Mu'in, F. (2011). Pendidikan Karakter: Konstruksi Teoritik \& Praktik. Yogyakarta: Remaja Rosda Karya.

Mujib, A. (2017). Teori Kepribadian dalam psikologi Islam. Cetakan kedua. Jakarta: Rajagrafindo Persada.

Rusn. (1998). Pemikiran Al-Ghazali Tentang Pendidikan. Yogyakarta: Pustaka Pelajar.

Sabri, M. A. (1995). Psikologi Pendidikan. Jakarta: Pedoman Ilmu Jaya.

Samani, M., \& Hariyanto. (2013). Konsep dan Model Pendidikan Karakter. Bandung: Remaja Rosdakarya.

Setiawan, W. (2016). The Spiritual Education Toward Insan Kamil In The Education Of Modern Humankind. 
Setiawan, W. (2018). Reward and Punishment Perspektif Pendidikan Islam ALMURABBI (Vol. 4 4). Retrieved from https:/ / bipublication.com/files/20160286.pdf.

Sudirman, S. A., Suud, F. M., Rouzi, K. S., \& Sari, D. P. (2019). Forgiveness and Happiness through Resilience. Al-Qalb: Jurnal Psikologi Islam, 10(2), 113-132.

Suud, F. M. (2018). Kepemimpinan Transformasional dan Implikasinya pada Pembentukan Budaya Jujur di Sekolah. Sukma: Jurnal Pendidikan, 2(2), 261-286. https:// doi.org/10.32533/02206.2018

Suud, F. M., Madjid, A., \& Sutrisno. (2019). The Study Of Educational Honesty Stages Implementation in an Indonesian School. Humanities \& Social Sciences Reviews, $7(4)$,

502-510. https:// doi.org/https:// doi.org/10.18510/hssr.2019.7467

Suud, F., \& Subandi, . (2018). Kejujuran dalam perspektif psikologi Islam. Jurnal Psikologi Islam, 4(2), 121-134. Retrieved from http://jpi.apihimpsi.org/index.php/jpi/article/view/44

Suyanto, T., Zen, I. M., Prasetyo, K., Isbandono, P., Gamaputra, G., \& Purba, I. P. (2018). The study perception of social sciences and law faculty students for hoax in social media. Journal of Physics: Conference Series, 953(1). https:// doi.org/10.1088/1742-6596/953/1/012151

Tafsir, A. (1996). Epistemologi untuk Ilmu Pendidikan Islam. Bandung: Fakultas Tarbiyah IAIN Bandung.

Tambak, S., \& Sukenti, D. (2020). Pengembangan Profesionalisme Guru Madrasah dengan Penguatan Konsep Khalifah. Hayula: Indonesian Journal of Multidisciplinary Islamic Studies, 4(1), 41-66. https:// doi.org/10.21009/004.01.03

Tobroni. (2008). Pendidikan Islam, Paradigma Teologis, Filosofis dan Spiritualitas. Malang: UMM Press. 